\title{
Smart Campus at the Universidad Militar Nueva Granada: Creation of Base Map and Applications for Campus Tree Monitoring*
}

\author{
Elsa Adriana Cárdenas Quiroga ${ }^{* *}$
}

\author{
Received: 24/07/2018 • Approved: 04/05/2020 \\ https://doi.org/10.22395/rium.v20n38a2
}

\begin{abstract}
The GIS smart campuses have been constituted as an efficient system that allows the integration of information from different agencies inside universities, with the use of geographic applications developed for different types of users.

This research describes general considerations to begin implementation of a smart GIS at the Nueva Granada Campus, in Cajicá. This phase was developed based on the generation of a campus base map, which is used as a spatial reference for the elaboration of all applications that require associated geographic information, as well as the implementation of a Gisweb system for the monitoring, verification, and updating of the campus trees. The result of the work provides the basis for subsequent systems and applications of location, mobility and efficacy management related with the academic and administrative activities in the university campus.
\end{abstract}

Keywords: database; GIS; information technology; mobile application; resource management; smart campus; smart city; smart systems; sustainable development; web service.

Concluded research. Research Project "Phase II- Proposal for the implementation of a smart campus at the Universidad Militar Nueva Granada. - Indoor Positioning, using “proximity sensors” with INV-IN-2394 code. Execution time: one year. Project financed by the Research Vice-Dean Office at the Universidad Militar Nueva Granada, Bogota, Colombia.

** MSc. in Environmental Management. Full Professor, Faculty of Engineering, Civil Engineering program. Email: elsa.cardenas@unimilitar.edu.co. Orcid: https://orcid.org/0000-0002-8587-4625 


\title{
Campus inteligente en la Universidad Militar Nueva Granada: creación de un mapa base y aplicaciones para el monitoreo de árboles en el campus
}

\begin{abstract}
Resumen
Los campus inteligentes GIS se han constituido como sistemas eficientes que permiten la integración de información de diferentes agencias al interior de las universidades con el uso de aplicaciones geográficas desarrolladas para distintos tipos de usuarios. Esta investigación describe las consideraciones generales para emprender la implementación de un GIS inteligente en el Campus de la Universidad Nueva Granada en Cajicá. Esta fase de desarrollo se fundamentó en la generación de un mapa base del campus, el cual es usado como referencia espacial para la elaboración de todas las aplicaciones que requieren información geográfica asociada, así como la implementación de un sistema Gisweb para el monitoreo, verificación y actualización de los árboles del campus. El resultado del trabajo brinda las bases para sistemas y aplicaciones subsiguientes para la ubicación, movilidad y administración de la eficiencia relacionada con las actividades administrativas y académicas en el campus universitario.
\end{abstract}

Palabras clave: base de datos; GIS; tecnologías de la información; aplicación móvil; manejo de recursos; campus inteligente; ciudad inteligente; sistemas inteligentes; desarrollo sostenible; servicio web. 


\section{INTRODUCTION}

A university campus is considered a miniature version of the city, which is characterized by a complex ecological system in search to unite the academic spaces harmoniously and balance all the functionality of investigation spaces with the common services, the university common wellbeing zones and the natural landscaping [1].

As cities, the behavior and elements that constitute a university campus require an efficient service that contributes with administration and environmental management [2].

To cover this problem, today, multiple universities such as Universidad de Pamplona [3],Universidad de los Andes [4], Universidad Pontificia Bolivariana [5], Universidad de Cartagena [6], Universidad del Magdalena [7] and Universidad del Valle [8], have begun to execute initiatives in the development of Smart Campuses, covering several fields, such as, urbanism and intelligent buildings, energy, environment, mobility, educational services, among others.

In the general framework, a Smart Campus is a system that uses technologies to be more competitive and to ensure a more sustainable future, with a symbiotic link of people networks, technology, infrastructure, consumption, energy and spaces [9].

Universidad Militar Nueva Granada, whose mission and vision are addressed to offer quality academic services, integrating within them activities related with teaching, research and the creation of an academic community. In the same way, the integration of services and activities have been established as one of its strategic aspects, facilitating and making its work more efficient, having an infrastructure with the newest technology as a factor of support for an efficient management of resources and processes [10].

In 2009, Universidad Militar Nueva Granada, in accordance with its vision and mission, began the construction of the largest University Campus in Colombia, and the third in Latin America. The magnitude of the Project and the complexity of all aspects related with its development and management, as well as the internal administration, have given evidence of the difficulties related to the administration of spaces, maintenance of installations, control of energy/hydraulic consumption, planning and organization of events, emergency and green buildings management, transportation and mobility, as well as sound levels modeling.

In order to offer solutions in harmony with strategic aspects of the university, this research's main objective is to release the methodological design that was implemented for the elaboration of a GIS web system that would allow the monitoring, verification and updating of the trees in the institution, as the first case on the application of the 
development of a smart campus. For that, the description of the processes implemented in the construction of the base map will be done. The base map represents one of the fundamental supplies in the management and monitoring of resources in the institution through the use of technologies. This map will also allow visualizing and constituting the general elements of the campus and will serve as the main source for the development of future applications that will feed the system in other fields in the institution.

\section{THEORETICAL FRAMEWORK}

The rapid worldwide urban growth [11], because of the inevitable tendency of the modernization and development [12-13], has resulted in important challenges in terms of governing and planning, which gives place to the changes that this activity generates over the economic, social and environmental structure in the territory [14].

The need to confront such challenges in an efficient and sustainable form has required the applications of technologies as a tool for a successful management in urban growth [15]. This synergy between urban management and information and communications technologies (ICT), has given place to the concept of smart city.

During the last century, this concept has been formulated by a great number of researchers from different disciplines and corporations [16], whose specific interests have generated multiple definitions that adapt their focus or investigation, such as information and communication technologies (ICT), the sustainable urban or community development through a learning focus based on knowledge, among others [17-18].

Considering that a consensus on the definition for this term does not actually exist, in this research framework, a local system of innovation supported by technological webs and artificial intelligence will be understood as smart city [19-20]. Its general objective consists of an interconnection and interoperation of systems and subsystems of a city to improve its social wellbeing, economic development and the conservation of the environment [21].

In a similar manner, the concept of smart campus makes reference to a digital strategic center, which fosters an "end to end" learning of an eco-system of knowledge, in which collaborative spaces and centralized information are created [22]. That frames the difference between a smart campus, and one that is not. This is done by the design and the conceptualization of an educational space, and not only by its architectural design, but it becomes into a learning space, which is socio-spatial, based on webs of collaboration that generate sustainable environments [6]. 
Authors, such as Galeano-Barrera and others [23], have identified a group of seven fundamental pillars, that sets gives the north to a university institution on how to become a smart campus; among them, environment, society, governance, infrastructure and mobility, health and research. These pillars are not necessarily static, reason why, every institution can adapt, reinforce or omit the areas of intelligence applicable to the Smart Campus design based on their needs and capabilities for an efficient transitional process [23].

Nowadays, an institution could not have been conceived as a group of coherent processes which allows the gathering, process, storage and distribution of data without the help of information technologies, specifically information systems and facilitates management and decision making for an internal resources control [24]. The majority of the smart campuses integrate information automated systems such as Transaction Processing Systems (TPS) and Enterprise Resource Planning Systems (ERP) in a Geographical Information System (GIS), where administrative transactions are processed and decision-making is facilitated for the planning of resources [25].

GIS are characterized for being systems that have the possibility of having their database distributed in different servers; and being able to access them via web communication, allowing access to the existing remote information. However, to mix information from different servers, this should have certain characteristics that allow interoperation with compatible formats under common standards [26].

For that, it is necessary to have agreements among owners, producers and users that facilitate the access and exploitation of the geographic information, as well as the application of norms, standards and specifications that regulate and guarantee the information interoperability, being The International Organization of Standardization (ISO) the most important organism in this process [27].

Considering the university campus as a complex system, as presented in figure 1, the scheme of the main components that serve as a reference to model the context base map of the Nueva Granada Campus of the Universidad Militar, it is important to take into account that the base map is the one containing the fundamental data and serves to construct or reference any other group of thematic data. 


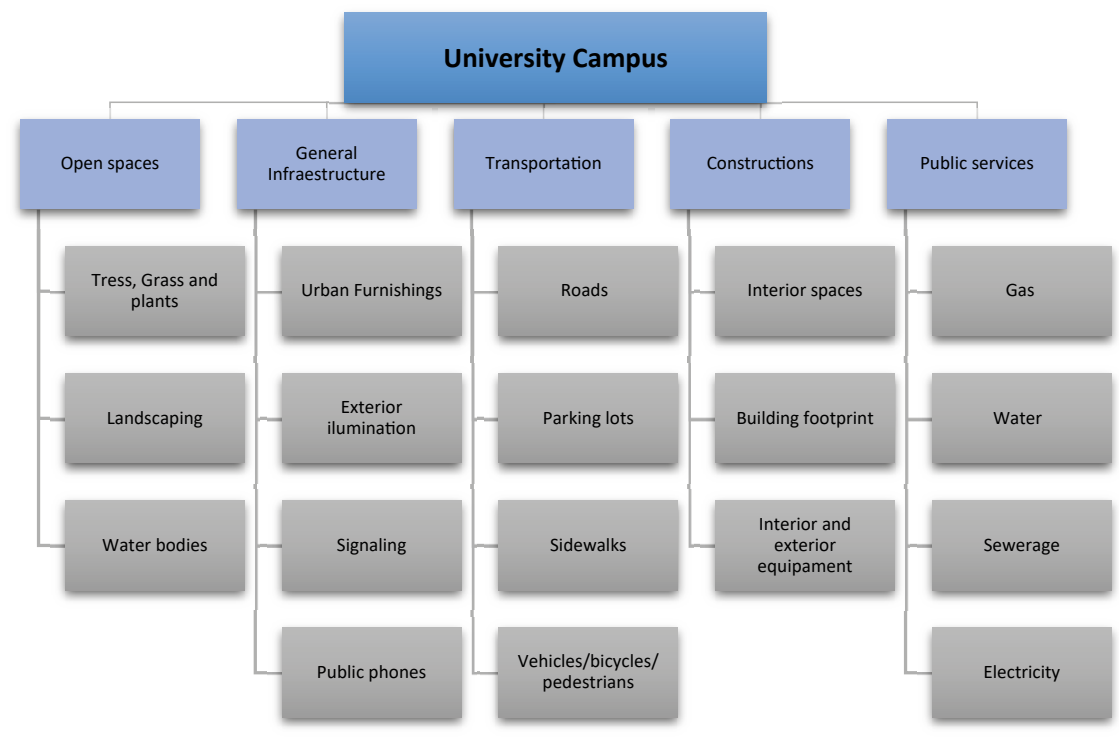

Figure 1. Main components of an academic university campus.

Source: Own elaboration.

The majority of the information is presented in figure 1. It is commonly found in the general university campus plans. Nevertheless, in most cases, data is stored in DWG format of a CAD system. For this reason, it is necessary to transform them into SIG system through the extraction of geo-referenced functional layers and the regeneration of geometries of entities that allow the construction of the base map.

ESRI's Local Government Information Model (LGIM) is a system that allows the development and elaboration of a Smart Campus [28]. It could be defined as a group of tools that adapt to the specific needs of a user, generating a pattern of common order, which allows the use of GIS as an information management tool for decision making to form a user community, use, adapt, and finally create new maps and applications [29].

Considering the non-existence of GIS servers at the Nueva Granada Campus, a model that works from the cloud is proposed, such as Software as a Service (SaaS) or software as the server [30]. This model of implementation corresponds to an application offered through the internet, which is offered by its creator, and can be used by several clients, keeping the privacy of personal data and the personalization of the application [31]. It is characterized to avoid the administration of servers, and to connect the information directly with the applications developed for the intelligent campus, through the use of ArcGIS Online [32]. The geographical portal model allows the access, visualization, consult and collaboration of the applications of the virtual campus among different user groups. 


\section{MATERIALS AND METHODS}

\subsection{Area of study}

The university campus of Universidad Militar Nueva Granada (UMNG) (figure 2) is located in the municipality of Cajicá, department of Cundinamarca, Colombia, with a total area of 75.5 hectares, of which $11 \%$ are destined for the construction of urban zones [33].

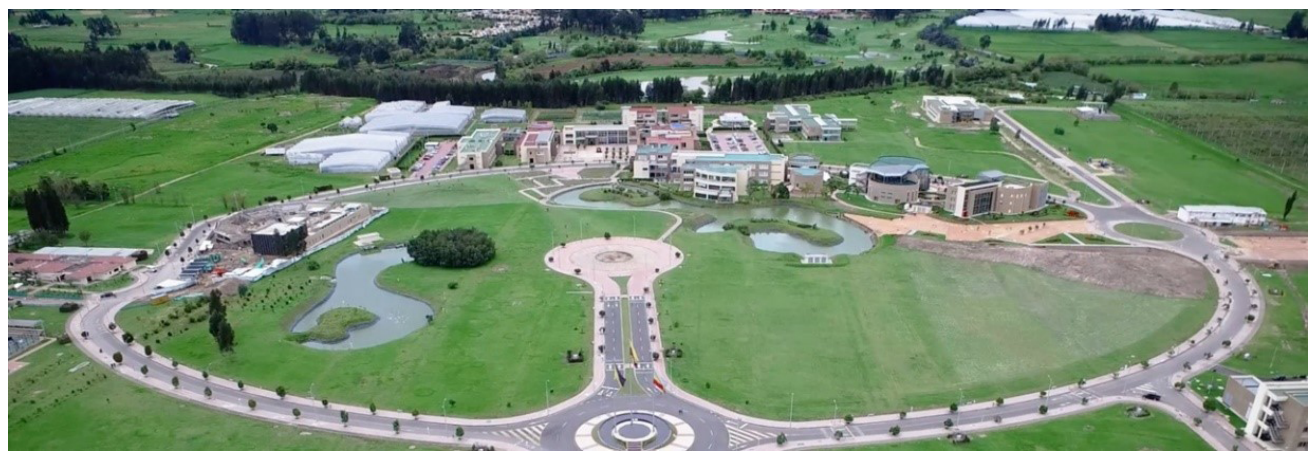

Figure 2. Nueva Granada Campus

Source: [33].

The physical infrastructure has a large number of urban works, such as, roads, sidewalks, trials, bicycle lanes, parking lots, urban furnishing, buildings, cafeterias, auditoriums, sports spaces, restaurants, greenhouses, collection center, water treatment plants, integration square, laboratories and an acoustic shell [33].

\subsection{Materials}

Due to the versatility that the software offers in the inter-operational process with other systems, this methodology was developed using ArcGIS. It allows, among other advantages, information integration processes with Computer Aided Design (CAD), Geographic Information System (GIS) and Building Information Modeling (BIM).

The supplies used for the development of this research are:

- Data on the infrastructure of the University Campus, given on CAD.

- Archives on Excel, with the location information, status, type, family, and other characteristics and properties relevant to the tree inventory to date at the university. 


\subsection{Methodology}

This research was developed dividing the process into two phases: the first one was the creation of a geo-visor elaborated through the publication of the institution's web map. The second was the creation of the application for the management of trees at the university.

\subsubsection{Creation of the Institutional Geo-visor}

\subsubsection{Information Preparation}

To begin the map construction of reference for UMNG, it was necessary to implement a series of preliminary tasks that allowed organize, extract and modify CAD data to ensure efficiency of later processes and final quality.

The first task inside this phase consisted on the organization of information. Considering how commonly different layers can be used to represent one element in CAD files, it was necessary to unify and clean data in such way that the final file would have as many layers as its number of elements (figure 3).

Within this process, it is important to consider that the zero-layer must not contain information and it must not be duplicated. The geometries handled in CAD files are points, polygon, lines and annotations. The last one must be saved in a different layer. For the 3D objects in CAD, the polygonal geometry mesh will be converted to a multi-patch element when being exported to GIS that corresponds to 3D geometry in ArcGIS [34] .
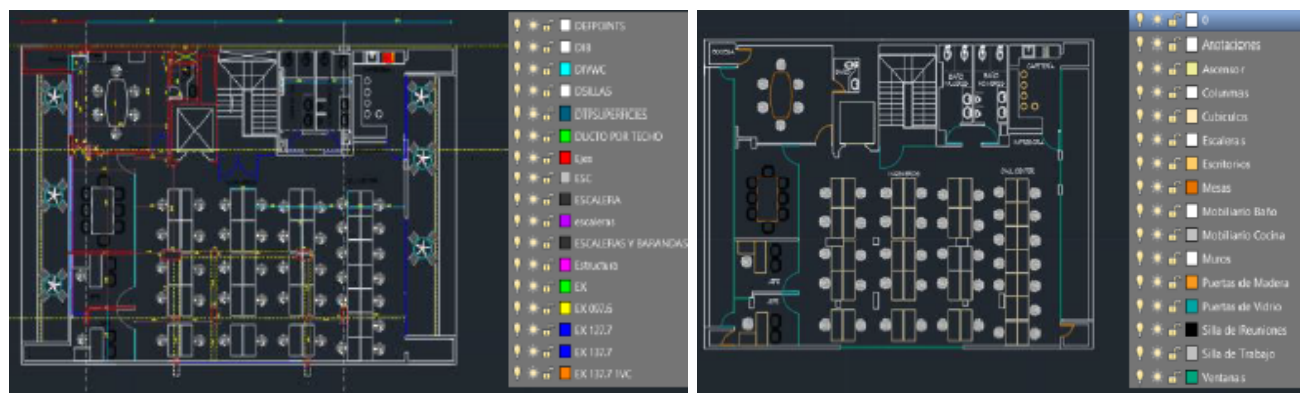

Figure 3. CAD Organization of information

Source: [34].

Afterwards, the CAD files were geo-referenced into ArcMap, allowing the location of the information spatially over the area in earth's surface where it belongs. Once the information was referenced, a selection of the fundamental layers for the construction of the reference map (such as walls, lower walls, windows, doors, columns, exterior spaces and water bodies, including roads) was done. This data was transformed into Shape-file 
files, corresponding in a spatial format data developed by ESRI, which allows the storage of non-topological geometries, together with attributes associated to them [35]. During this phase, the multiple lines that were completely closed were transformed into a polygon.

For an easy access and administration of information, it was necessary to store it in a Geo-database, or spatial data base, whose structure allows the centralization of a large quantity of alpha-numeric and spatial information in an organized manner [36]. Likewise, its structure allowed at a later time to correct topological errors, based on a definition of rules which specify the spatial relationships between allowed entities, to maintain the spatial integrity of data [37]. As a result, CAD layers were extracted and SIG was integrated, as shown in figure 4.
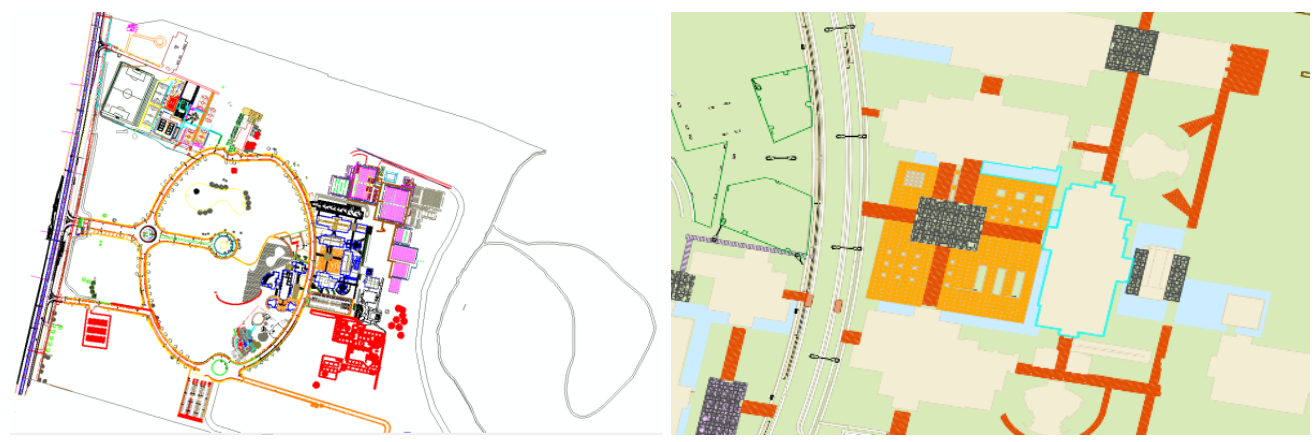

Figure 4. Left: Extraction of functional CAD layers. Right: SIG functional layers Source: Own elaboration.

\subsubsection{Publication of a service of vector tiles}

Vector tiles are small pieces of data with vector character, which are geo-referenced and they reach a spatial, adjacent and rectangular extension. As the map "raster" tiles, its purpose is to give support for fast map services, which can take advantage of pre-rendering, use of caches and concurrent petitions. Its application is designed for visualization services, where geometric objects are selected, combined, simplified and cut to generate small vector tiles, which can be delivered to client devices and application, getting easily adapted to its resolution with cartographic styles, different in function from user's needs [38].

The publication of the service was done through software ArcGIS Desktop. For this, it was necessary to enter via interface into the university's online ArcGIS account. Thereafter, it was necessary to accomplish the publication as a vector tiles service. Entering the university account contents into the web, it was possible to verify the vector tile layers publishing, which contain the base map information from Nueva Granada Campus (figure 5). 


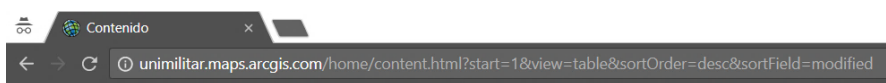

\section{Contenido}

Mi contenido

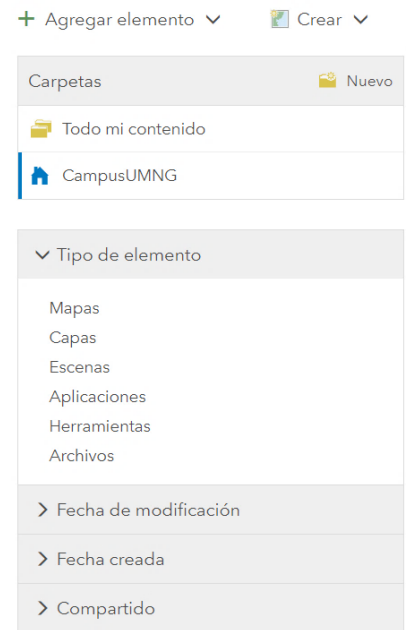

Q Buscar CampusUMNG

1 - 6 de 6 en CampusUMNG

$\square$ Título

$\square$ GUMNG_basemap_APP

$\square$ QUMNG_basemap

$\square$ 㗐UMNG_basemap_all

目UMNG_basemap_all

$\square$ 㗐UMNG_basemap

圈UMNG_basemap

Web Mapping Application

Web Map

Tile Layer (alojado)

Service Definition

Tile Layer (alojado)

Service Definition

Figure 5. Storage of tile layers

Source: Own elaboration.

\subsubsection{Creation of the Web Map}

With the purpose of creating an application that allows UMNG users to identify and spatially locate the institution's elements, a web map was created through the ArcGIS Online Platform (figure 6). For this, a layer of vector tiles was added to the Map Viewer page. Then, it was configured to the application style, the labels, emergent windows that allow an efficient visualization of attributes of spatial elements. Finally, the configuration of different tools that allow the efficient use of the website was added. It is important to point out that the option of a map aspect varies in the account's configuration function and the size of the web browser's window. 


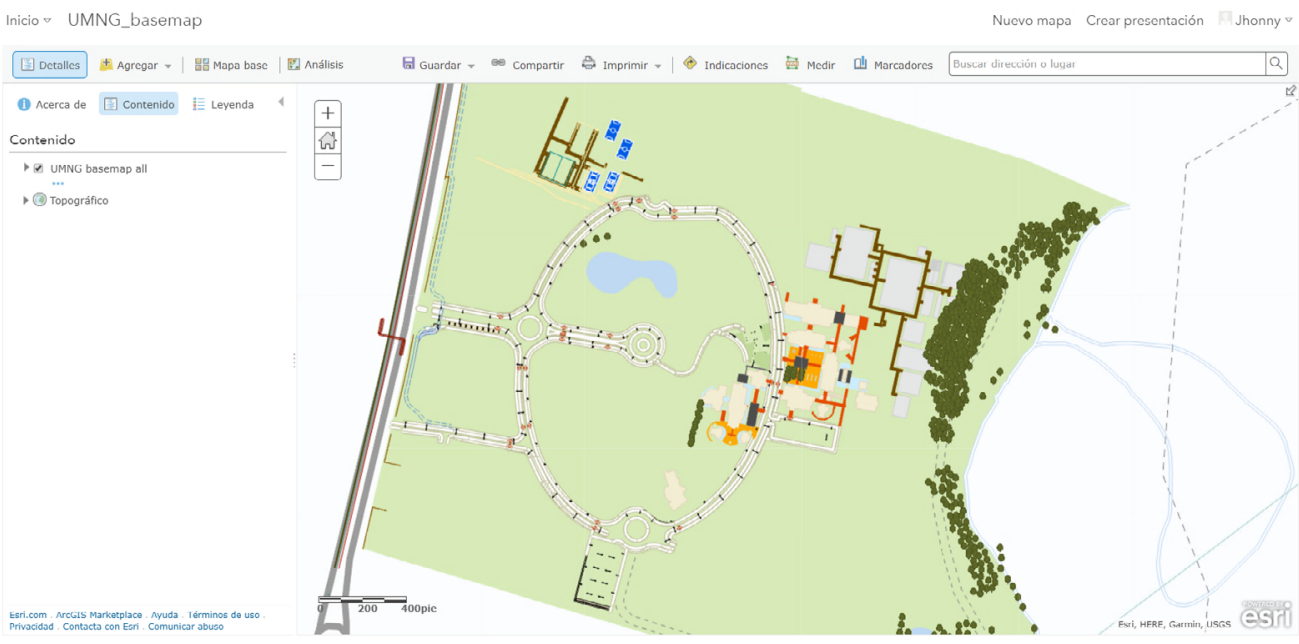

Figure 6. Creation of the institution's web map in ArcGIS Online Source: Own elaboration.

As a result, it was possible to configure an application, in which the user can visualize the information in a $2 \mathrm{~d}$ model, perform zoom or distance tasks, look for a site by entering name or coordinates, consult, turn layers on or off; and define if a street map, a satellite image or a topographical map will be used as a support for additional orientation of the vector campus information (figure 7).

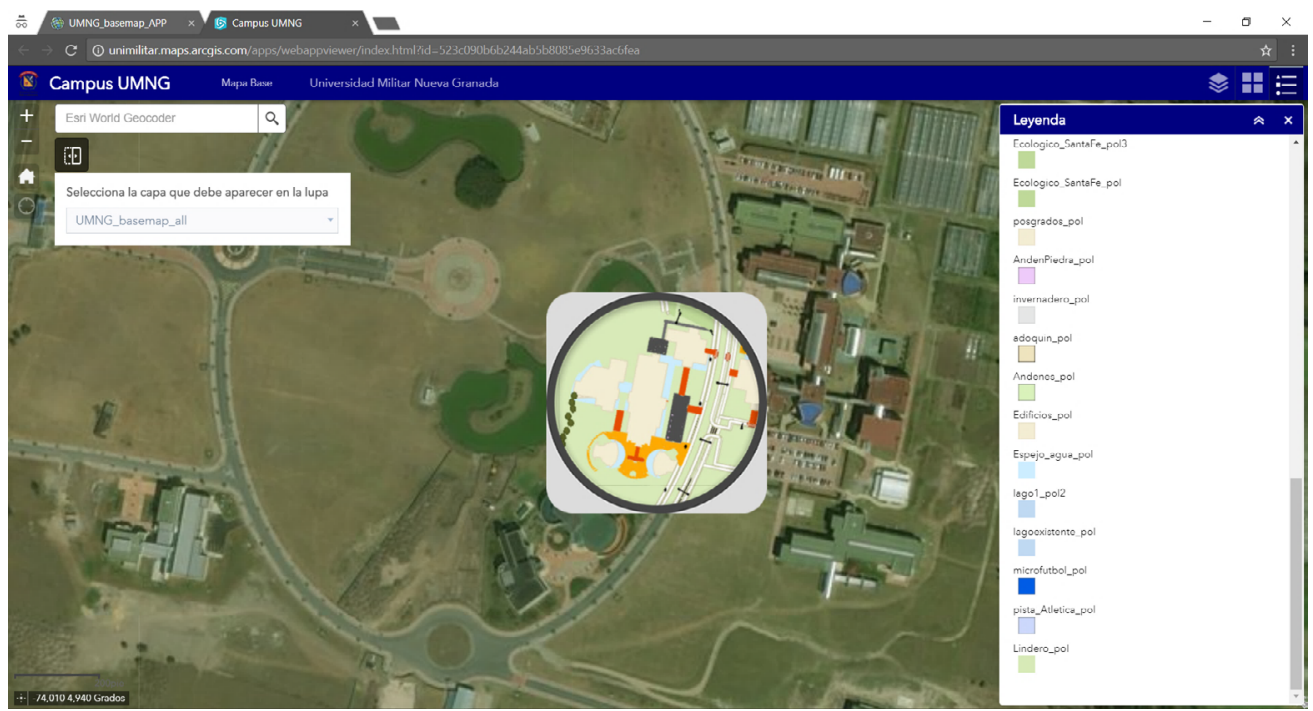

Figure 7. Application of the UMNG campus for the view of geographic information. Source: Own elaboration. 


\subsubsection{WEB Application for the management of trees at the UMNG}

After generating the base map for the campus, the implementation of the geographic application was done to assist with the tasks of verification, monitoring, and updating of the tree component in Nueva Granada Campus, as it is now explained.

\subsubsection{Information preparation}

The information related to trees at the UMNG Campus was prepared in an Excel file. To integrate it in the system, a point's vector layer was created in ArcGIS; and stored in a geo-database, in order to create domains as a method to force data integrity.

The domains are rules stipulated for the field of information, which limits the values that can be stored in the entity table. This way, the field can only store numeric data, text type, dates or unique identifiers according to the rules defined for this entity.

In the design of the data structure, only information that can be registered by the user who does the field monitoring process was included (table 1). While coordinates of a point represent the most important geographic characteristic of the entity, these were not included in the format, for the application captures this information automatically.

Table1. Attributes associated to the tree feature

\begin{tabular}{lll}
\hline \multicolumn{2}{c}{ Attributes } \\
\hline NO Tree NO & Aspect & Support with drawal \\
Tree ID & Mechanical damage & Clearing \\
Family & Handling Proposal & Phytosanitary control \\
Species & Date & Chipper addition \\
Common name & Validation of reported specie & Phytosanitary damage tree site \\
Diameter Base $(\mathrm{cm})$ & Survivalverification & Observ. Phytosanitary damage tree site \\
Total Height $(\mathrm{mt})$ & Stakeout & Mechanical damage tree site \\
Phytosanitary Status & Pruning & Obser. Mechanical damage tree site \\
N. Location & Chemical fertilization & NO replacement tree \\
Location & Organic fertilization & NO replacement location \\
\hline
\end{tabular}

Source: Own elaboration.

\subsubsection{Publication of the Institutional Geo-visor Layer}

Once the preparation phase was finished, the information was published as a layer of entities in the institution geo-visor, following the same procedure as exposed in the previous phase for the publication of a service of vector tiles.

Figure 8 shows a web map with the punctual layers of trees, together with the base information generated for the Nueva Granada Campus, which serves as a spatial thematic reference for the user. 


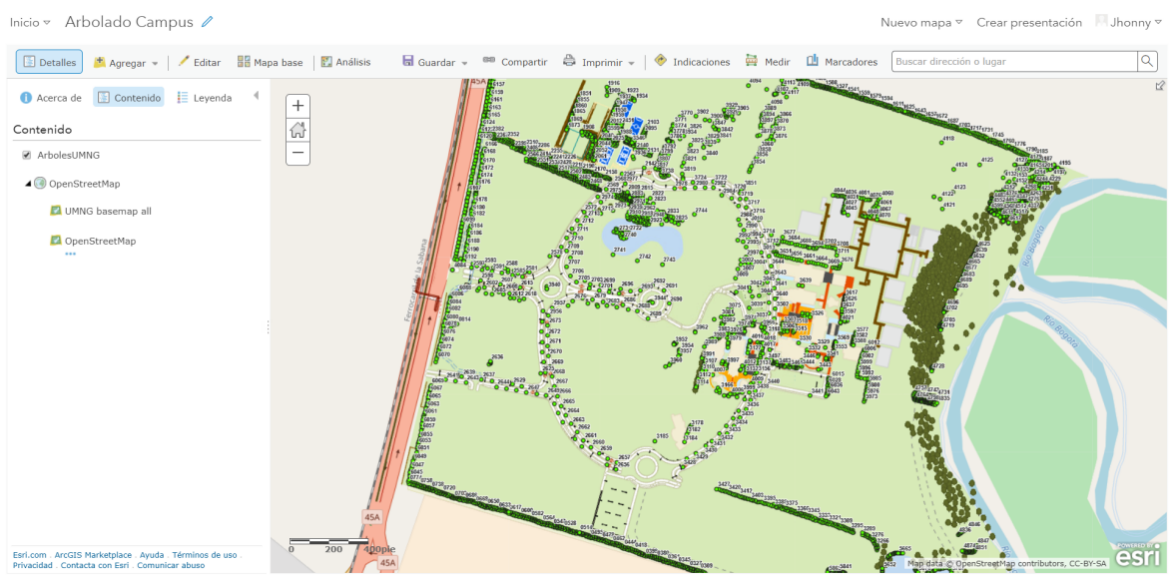

Figure 8. Visualization of tree entities over the information of reference in the application Source: Own elaboration.

\subsubsection{Data entry}

For data entry, the mobile ArcGIS Collector application was used to capture information in the field using web maps [39]. This application, available for Android as well as iOS, allow users to work over any published map on the ArcGIS Online Organization.

The application allows the user to select a tree, object of revision, edit a series of the established fields in the entry format; and take pictures to evidence the state of the individual being revised (figure 9).

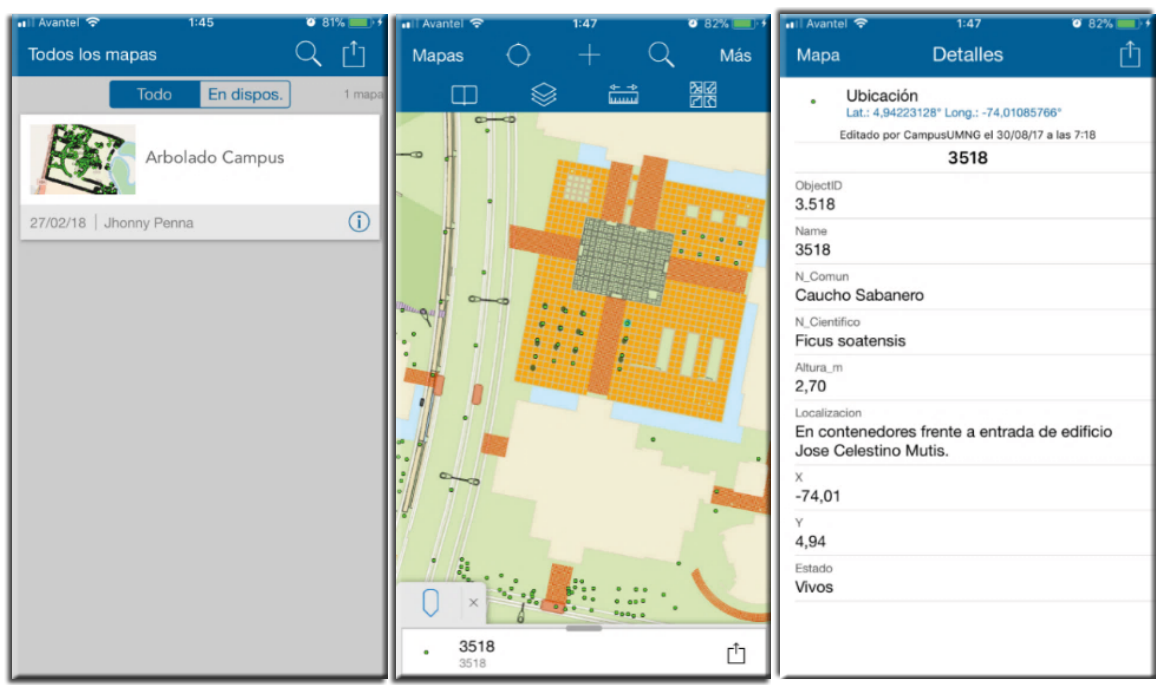

Figure 9. Visualization of information in Collector for ArcGIS

Source: Own elaboration. 


\subsubsection{Creation of the Control Board}

The control dashboards are management tools that serve to diagnose a situation through the visualization of useful information that allows performance measurement using data tools. For the application of the tree in campus at the university, a board was control-created with the Operations Dashboard option, which allows monitors the tracing files of an organization, as well as evaluating the configuration to be monitored in real time within the state of data collection in the field and of daily operations from a dynamic board.

For the management of trees, the university board allows to perform consulting tasks related to the status of the verification process of the number of trees registered and the actual state for each one. In addition, the emergent window allows to visualize the information of a specific entity in a simple and practical manner (figure 10).

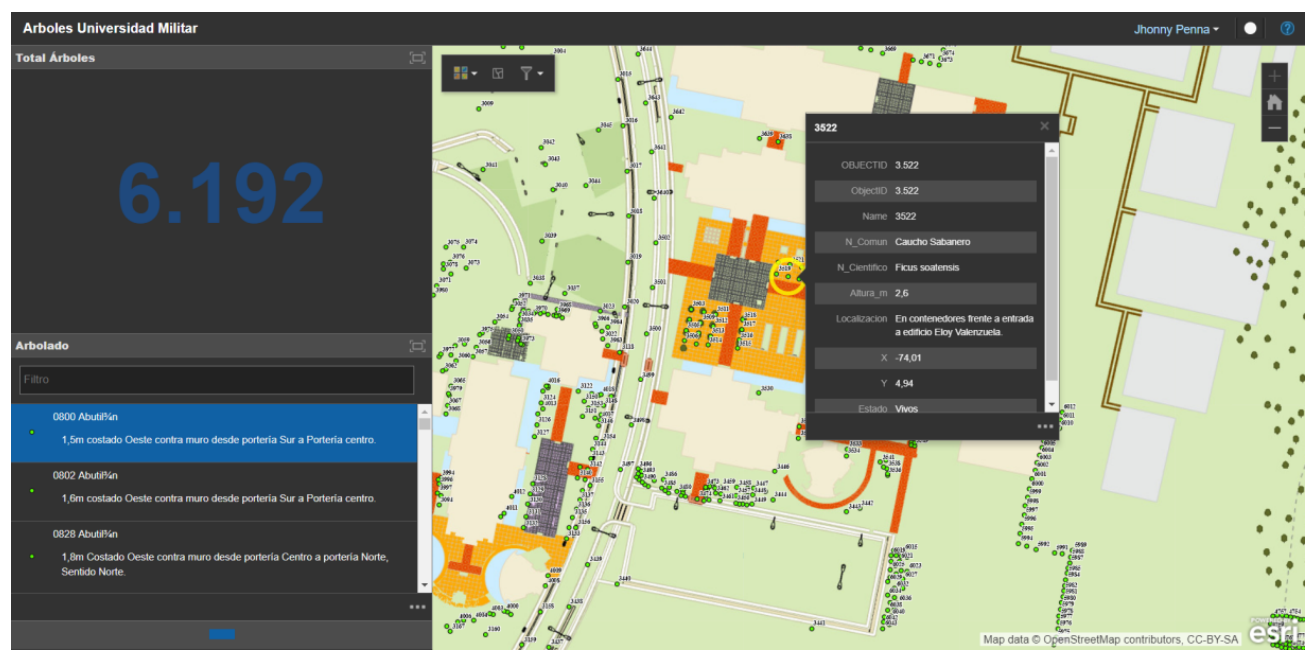

Figure 10. Operation Board

Source: Own elaboration.

\section{CONCLUSIONS}

The generation of the base map and the creation of the application for the monitoring of trees at the Nueva Granada Campus represent one of the first phases of the GIS Smart Campus. Its development offers the institution the possibility of having a system that provides and integrates comprehensive information through a model that avoids data multiplicity; and provides services and applications to consult, visualize and edit information from different access points. It also serves to board different needs for UMNG users, offering opportunities for I+D technology, "Smart Cities". In general, the system empowers the teaching and learning processes, while also improving the 
management process as well as the quality of lives for people through sceneries, in which users can interact with their environment.

The application generated in the project's framework represents only one example of the multiple questions and works that could be developed through a Smart Campus. From the reference information obtained in the elaboration of the base map, the development of 3D models could continue for the process of location inside the university buildings, control administration of classroom access and offices in real time. These processes facilitate student's learning through applications that allow the use of educational resources that contribute to intellectual development, better people mobility, as well as an optimization of resources.

It is important to point out that the development of the proposed objectives evidences the need of implementing software programs. This would allow the generation of inter-operating processes for the integration of information, which is supplied by different formats, fostering in this way the development of inter-connected systems under a standardized infrastructure.

\section{AKNOWLEDGMENTS}

This article was derived from the research Project Phase II-a proposal for the implementation of an Intelligent Campus at Universidad Militar Nueva Granada. Indoor positioning, with the use of proximity sensors with INV-ING-2394 code, financed by the Vice-rectory of research at the Universidad Militar Nueva Granada, Bogota, Colombia.

\section{REFERENCES}

[1] H. M. Alshuwaikhatand I. Abubakar, "An integrated approach to achieving campus sustainability: assessment of the current campus environmental management practices. Journal of Cleaner Production", Journal of Cleaner Production, vol. 16, 16, pp. 1777-1785, 2008. https://doi.org/10.1016/j.jclepro.2007.12.002

[2] D. Rico-Bautista, J. Parra-Valencia y C. D. Guerrero, “IoT: Una aproximación desde ciudad inteligente a universidad inteligente.” Revista Ingenio UFPSO, vol. 13, 1, pp. 9-20, 2017.

[3] Universidad de Pamplona. Macro-políticas, 2005. [Online] Available: http://www.unipamplona. edu.co/unipamplona/portalIG/home_1/recursos/rectoria/31032009/macropoliticas.jsp

[4] Portafolio. Universidad de los Andes apuesta por el campus inteligente. 2014. [Online] Available: https://www.portafolio.co/tendencias/universidad-andes-apuesta-campusinteligente-57238. [Last accesed: April 5th, 2020].

[5] UPB. Campus UPB se proyecta como ciudad inteligente. 2016. [Online] Available: https:// www.upb.edu.co/es/noticia/red_inteligente. [Last accesed: April 4th, 2020]. 
[6] N. Maza y M. Orozco, "Modelo de gestión estratégica para el desarrollo de un campus inteligente basado en conceptos de Smart City en la Ciudad de Cartagena - Campus Piedra de Bolívar (Trabajo de grado). Fa.c Ing., Univ., de Cartagena, Cartagena, Colombia, 2017.

[7] S. Prieto Mejía. (2014, mayo, 26 - 28). La Incorporación de Tecnologías Educativas en la Universidad del Magdalena bajo un enfoque de Smart Campus, presented at Cuarta Conferencia de Directores de Tecnología de Información, Tical2014 Gestión de las Tics para la Investigación y la Colaboración., [Online]. Available: https://www.redclara.net/images/ TICAL/actas_tical2014.pdf.

[8] NVC, "El 30\% de las aulas de Univalle serán inteligentes y se construirán 38 nuevos salones.” Noticiero La nueva voz de Cartago 2018 [Online]. Available: https://noticiasnvc. com/2018/07/11/el-30-de-las-aulas-de-univalle-seran-inteligentes-y-se-construiran-38nuevos-salones. [Last accesed: April 4th, 2020].

[9] B. Sánchez-Torres, J. et al. "Campus inteligente: Tendencias en ciber-seguridad y desarrollo futuro". Revista Facultad de Ingeniería, vol. 27, 47, pp. 93-101, 2018. https://doi. org/10.19053/01211129.v27.n47.2018.7807

[10] UMNG, “Misión, visión y objetivos institucionales," [Online]. Available: https://www.umng. edu.co/transparencia/estructura-organica-y-talento-humano/mision-y-vision. [Last accesed: April 1st, 2020].

[11] Department of Economic and Social Affairs of the United Nations, Population Division. (2019) World Urbanization Prospects: The 2018 Revision. New York, United States. [Online].

[12] H. Xie, Y. Zhang and K. Duan, "Evolutionary overview of urban expansion based on bibliometric analysis in Web of Science from 1990 to 2019," Habitat International, vol. 95, p. 102100, 2020. https://doi.org/10.1016/j.habitatint.2019.102100

[13] M. Marzouk y A. Othman, "Planning utility infrastructure requirements for smart cities using the integration between BIM and GIS." Sustainable Cities and Society, vol. 57, p. 102120, 2020. https://doi.org/10.1016/j.scs.2020.102120

[14] K. Shi, J. Shen, L. Wang,M. Ma y Y. Cui, "A multi-scale analysis of the effect of urban expansion on PM2.5 concentrations in China: Evidence from multisource remote sensing and statistical data". Building and Environment, vol. 174, p. 106778, 2020. https://doi.org/10.1016/j. buildenv.2020.106778

[15] J. Sujata, S. Saksham. G. Tanvi y Shreyad, "Developing Smart Cities: An Integrated Framework.” Procedia Computer Science, vol 93, pp. 902-909, 2016. https://doi.org/10.1016/j. procs.2016.07.258

[16] A. Ramaprasad, A. Sánchez-Ortiz y T. Syn, A Unified Definition of a Smart City, Janssen M. et al. (eds) Gobierno electrónico. EGOV 2017. Lecture Notes in Computer Science ed., vol. 10428, Springer: Cham, 2017. https://doi.org/10.1007/978-3-319-64677-0_2. 
[17] J. Laufs, H. Borrion y B. Bradford, "Security and the smart city: A systematic review" Sustainable Cities and Society, vol. 55, p. 102023, 2020. https://doi.org/10.1016/j. scs.2020.102023.

[18] A. Camero y E. Alba, "Smart City and information technology: A review" Cities, vol. 93, pp. 84-94, 2019. https://doi.org/10.1016/j.cities.2019.04.014.

[19] N. Komninos, Intelligent Cities and Globalisation of Innovation Networks, 1st Edition ed., London: Routledge, 2008, p. 320. https://doi.org/10.4324/9780203894491.

[20] Z. Ullah, F. Al-Turjman, L. Mostarda y R. Gagliardi, “Applications of Artificial Intelligence and Machine learning in smart cities”, Computer Communications, vol. 154, pp. 313-323, 2020. https://doi.org/10.1016/j.comcom.2020.02.069.

[21] M. Lom y O. Pribyl, "Smart city model based on systems theory." International Journal of Information Management, vol. 56, p. 102092, 2021. https://doi.org/10.1016/j. ijinfomgt.2020.102092.

[22] J. W. P. Ng, N. Azarmi, M. Leida, F. Saffre y P. D. Afzal, “The Intelligent Campus (I Campus): End-to-End Learning Lifecycle of a Knowledge Ecosystem.” In 2010 Sixth International Conference on Intelligent Environments, 2010, pp. 332-337.

[23] C. Galeano-Barrera, D. Bellón-Monsalve, S. A. Zabala-Vargas, E. Romero-Riaño y V. Duro-Novoa, "Identificación de los pilares que direccionan a una institución universitaria hacia un smart-campus.” Rev.investig.desarro.innov, vol. 9, 1, pp. 127-145, 2018. https://doi. org/10.19053/20278306.v9.n1.2018.8511.

[24] A. Fernández-Valmayor, J. Cristobal, A. Navarro, A. Fernández-Pampillón, J. Merino, M. Peralta y Y. Roldán, “El campus virtual de la Universidad Complutense de Madrid.” Pixel-Bit, Revista de Medios y Educación, p. 55, 2008.

[25] F. Ledezma Perizza, "Empleo de Sistemas de Información Geográfica, Datos de Sensoramientoremoto y Fuentes de Acceso Libre Global, como herramienta para modelar agua, energía y cambio climático en Bolivia.” Acta Nova, vol. 5, 4, pp. 477-520, 2012.

[26] IGAC, Mejora de los sistemas de cartografía del territorio colombiano, Bogotá D.C.: IGAC, 2007.

[27] M. Bernabé-Poveda y. C. López-Vázquez, Fundamentos de las Infraestructuras de Datos Espaciales, Madrid: UPM-Press, Serie Científica. ISBN: 978-84-939196-6-5, 2012.

[28] A. Sanchis, A. Arnal, W. Moreno, V. Sanchis, L. Díaz, J. Huerta y M. Gould, viscaUJI: campus inteligente como IDE loc, Madrid: III Jornadas Ibéricas de Infraestructura de Datos Espaciales, 2012.

[29] ESRI, “Local Government Information Model” [Online]. Available: https://solutions.arcgis. com/local-government/help/local-government-information-model/. [Last accesed: April $\left.13^{\text {th }}, 2020\right]$. 
[30] M. Raza, F. Hussain, O. Hussain, M. Zhao y Z. u. Rehman, "A comparative analysis of machine learning models for quality pillar assessment of SaaS services by multi-class text classification of users' reviews." Future Generation Computer Systems, vol. 101, pp. 341-371, 2019. https://doi.org/10.1016/j.future.2019.06.022.

[31] M. Elsayed y M. Zulkernine, "Offering security diagnosis as a service for cloud SaaS applications." Journal of Information Security and Applications, vol. 44, pp. 32-48, 2019. https://doi.org/10.1016/j.jisa.2018.11.006.

[32] K. B. ChanalBadia, "Gestión y difusión de los proyectos Smart City con la plataforma ARCGIS.” Esri, España, 2014.

[33] Universidad Militar Nueva Granada, "Proyecto Campus Nueva Granada." [Online]. Available: https://www.umng.edu.co/proyecto-campus. [Last accesed: April 14th, 2020].

[34] ESRI, Infraestructura y modelos 3D para la gestión de edificaciones y ciudades [Material del aula], Bogotá, 2018.

[35] ESRI, “Shapefile Technical Description”. 1998. [Online]. Available: https://www.esri.com/ library/whitepapers/pdfs/shapefile.pdf. [Lst accesed: April 10th, 2020].

[36] Y. Sosa Reyes y J. Villatoro, "Creación de una geo-database de los archivos geodésicos de la dirección general de catastro y geografía, Honduras." Revista ciencias espaciales, vol. 8, $\mathrm{n}^{\mathrm{o}}$ 1, pp. 509-519, 2015. https://doi.org/10.5377/ce.v8i1.2064.

[37] ESRI, “ArcGIS 9 Geo-database workbook.” [Online]. Available: http://downloads.esri.com/ support/documentation/ao_/697GeodatabaseWorkbook.pdf.

[38] E. López, R. Béjar,. J. Barrera, F. J. López-Pellicer, A. F. Rodríguez y. P. Abad, “Servicios de visualización INSPIRE basados en teselas vectoriales.” Revista Mapping, vol. 27, 187, pp. 38-46. ISSN: 1131-9100, 2018.

[39] ESRI, “Collector for ArcGIS” [Online]. Available: https:/www.esri.com/es-es/arcgis/ products/collector-for-arcgis/overview. [Last accesed: April 11th, 2020].

[40] A. M. Ballvé, “Creando conocimiento en las organizaciones con el Cuadro de Mando Integral y el Tablero de Control.” Revista de Contabilidad y Dirección, pp. 13-38, 2006. 